\title{
THE BIOLOGY OF THE COMMON PRAWN, LEANDER SERRATUS PENNANT
}

\author{
By G. R. Forster, B.Sc.
}

From the Plymouth Laboratory

\author{
(Text-figs. I-I4)
}

\begin{tabular}{|c|c|c|c|c|c|c|c|c|c|c|}
\hline & & & & CONT & ENTS & & & & & \\
\hline Introduction & & & & & & & & & & PAGE \\
\hline & & - & - & . & - & - & . & - & - & 333 \\
\hline $\begin{array}{l}\text { Methods } \\
\text { Age and growth }\end{array}$ & & & - & . & - & - & & - & - & 334 \\
\hline Age and growth & & & & & . $\quad$. & . & . & - & . & 335 \\
\hline The $1950 \mathrm{O}-\mathrm{g}$ & oup & (i.e & orood & of the & year) & . & . & . & . & 335 \\
\hline Comparison o & the & 1949 & ind 19 & 950 ye & ar groups & & & & . & 338 \\
\hline Later growth & ff th & $\mathrm{ma}$ & & . &.$\quad$. & . & . & . & . & 342 \\
\hline Later growth & ff th & fen & & . & . & & & & . & 342 \\
\hline Breeding . & . & . & . & . & . & & . & . & . & 348 \\
\hline Males & . & . & . & . & . & & . & $\cdot$ & . & 348 \\
\hline Females . & . & . & . & . & . & & $\cdot$ & & & 348 \\
\hline Period of egg- & carri & & . & . & . & • & . & $\cdot$ & . & 349 \\
\hline Distribution and & $\mathrm{mig}$ & ratio & & . & . & & 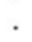 & & . & $35 \mathrm{I}$ \\
\hline Metamorphos & $s$ of & the 1 & & . & . & & . & v & . & $35 \mathrm{I}$ \\
\hline Distribution o & the & $\mathrm{O}-\mathrm{g}$ & & . & . & & • & & & $35 \mathrm{I}$ \\
\hline Distribution o & f the & I-ye & -old g & group & . & & . & • & . & 353 \\
\hline Food . . . & . & . & . & . & . & • & . & - & . & 354 \\
\hline Notes on the & tom & ch $\mathrm{c}$ & atents & & . & & - & & & 355 \\
\hline Notes on behavi & our & . & . & . & . & & . & . & & 357 \\
\hline Summary . & . & . & . & . & . & & . & & & $35^{8}$ \\
\hline References & . & . & . & . & . & & . & & . & 359 \\
\hline
\end{tabular}

\section{INTRODUCTION}

This work was undertaken at the suggestion of Mr F. S. Russell that little was known about the natural history of even so familiar a species as Leander serratus, the common prawn of the English Channel, which may at times form a valuable natural resource to the inshore fishermen. Attention was therefore chiefly concentrated on its growth rate and breeding biology. In spite of the long breeding season the statistical method of studying growth was adopted when preliminary results appeared successful. By this method additional data could be obtained on distribution and migration. In the closely related genus Crangon, growth has been shown to be retarded under laboratory conditions (Nouvel \& van Rysselberge, I937), so that an experimental study could not be relied on to give a picture of the normal life history. Höglund's recent monograph (I943) has treated Leander squilla in great detail. However, this species differs considerably in size and distribution from L. serratus, 
and it was felt that a similar study in the Plymouth area would not be mere repetition; in fact the biology of L. squilla itself differs somewhat in the two districts.

Acknowledgement is due to the Department of Scientific and Industrial Research for financial assistance in the form of a maintenance allowance, and to the crews of the research ships of the Plymouth laboratory for their help in collecting. Mr W. Searle's experience of the Plymouth trawl fishery for prawns also proved a great benefit.

\section{METHODS}

Prawns were caught by three methods: trawling, hand-netting, and with baited traps or hoop-nets.

The trawl used from the motor boat Gammarus was identical with the commercial prawn trawls, consisting of a $6 \mathrm{ft}$. beam with $\mathrm{I}$ in. mesh netting on the wings and head and $\frac{3}{4}$ in. mesh in the cod end. Trawling grounds near Plymouth are described in the Plymouth Marine Fauna (Marine Biological Association, I93I). The best grounds are located chiefly in muddy areas, sometimes a little rough, or near rocks.

Several patterns of hand-net were used, a pear-shaped frame for rock pools and a rectangular frame for walls or pier piles. Half-inch mesh netting was found suitable for all except the youngest stages, for which stramin was necessary. The most successful places for hand-netting were pier piles and undercut rocky gullies or crevices where the larger brown algae were absent.

Twelve prawn traps were constructed in the form of miniature lobster pots $2 \mathrm{ft} . \times \mathrm{I} \mathrm{ft} . \times 8$ in. covered with $\frac{1}{2}$ in. mesh netting. They were laid overnight in fleets of four, baited with fish. Catches varied considerably from trap to trap, usually one out of the four being particularly successful. The largest catch from any one trap was 37 prawns. At Paignton, additional catches were made with hoop-nets kindly loaned by $\mathrm{Mr}$ S. Underhay. These nets were set after dark in the Laminaria zone and hauled at about quarter-hourly intervals, the technique being to raise the net slowly and gently at first, when the prawns remain clinging to the bait. If the net is given a sharp tug some are disturbed and escape.

Prawns were always measured in fresh condition, owing to the curvature of the abdomen in most preserved specimens. In all cases the total length (tip of the rostrum to base of the spines on the telson) was measured with dividers while the animal rested in its normal upright position on a glass plate. Living prawns could be induced to sit quietly in this position. Although an occasional specimen was taken with a damaged telson or rostrum, with practice it was easy to estimate the extra few millimetres accurately. This method has the advantage of being suitable for all sizes of prawns. Variations in the rostral length, though tending to increase the spread of the results, did not hinder the 
separation of different year groups. Measurement of the carapace length alone, though suitable for adults, was virtually impossible for juveniles, and had two further possible disadvantages. An error of $\frac{1}{2} \mathrm{~mm}$. is much greater relative to the carapace than to the total length. Secondly, the carapace might undergo heterogonic growth while the ovary is ripening.

Collections were started in October I949 and the observations continued until October I950.

\section{AGE AND GROWTH}

The I950 O-Group (i.e. Brood of the Year)

Juvenile and post-larval stages belonging to the I950 O-group of Leander serratus were first taken from shore pools at Wembury in the second week of July of that year. They had not been found during the previous spring tides at the end of June, and therefore it is unlikely that many arrived before the first week of July. Very small prawns also appeared in the Sound at about the same time, their size frequencies being shown in Fig. I. The Wembury catch

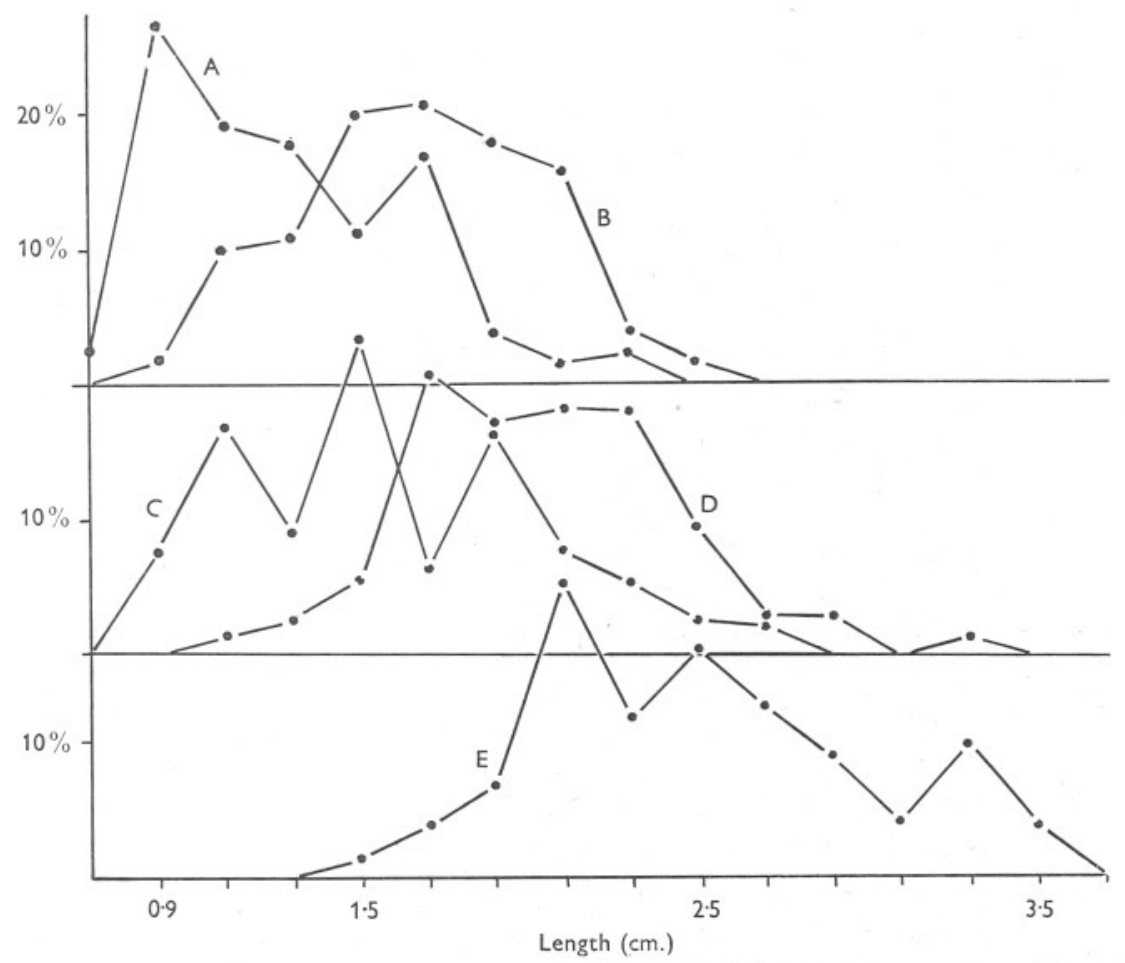

Fig. I. Leander serratus. Percentage size distribution of O-group prawns. A, Rum Bay (Plymouth Sound), 24 July I950 (136). B, Wembury (outside Sound), I4 July I950 (I27). C, Rum Bay (pool at mid-tide level), 3 Aug. 1950 (77). D, Rum Bay (low-water springs), 3 Aug. I950 (72). E, Rum Bay (low-water springs), 29 Aug. I950 (I82). 
is seen to contain many more prawns in the $\mathrm{I} \cdot 7, \mathrm{I} \cdot 9$ and $2 \cdot \mathrm{I} \mathrm{cm}$. groups than those from Rum Bay. At first sight this larger-sized population might be thought to be older or to have grown faster, but catches from Rum Bay on 3 August (Fig. I) showed that the average size increased towards L.W.S.T. level. Therefore the Wembury catch may have been from a slightly lower level on the shore. The growth of these juvenile prawns is shown in a comparison of the catch of 3 August at L.w.s. with that of 29 August. It is seen that the whole curve has moved roughly $0.5 \mathrm{~cm}$. to the right. There appears to have been only very little further recruitment of small individuals on the left-hand side of the graph.
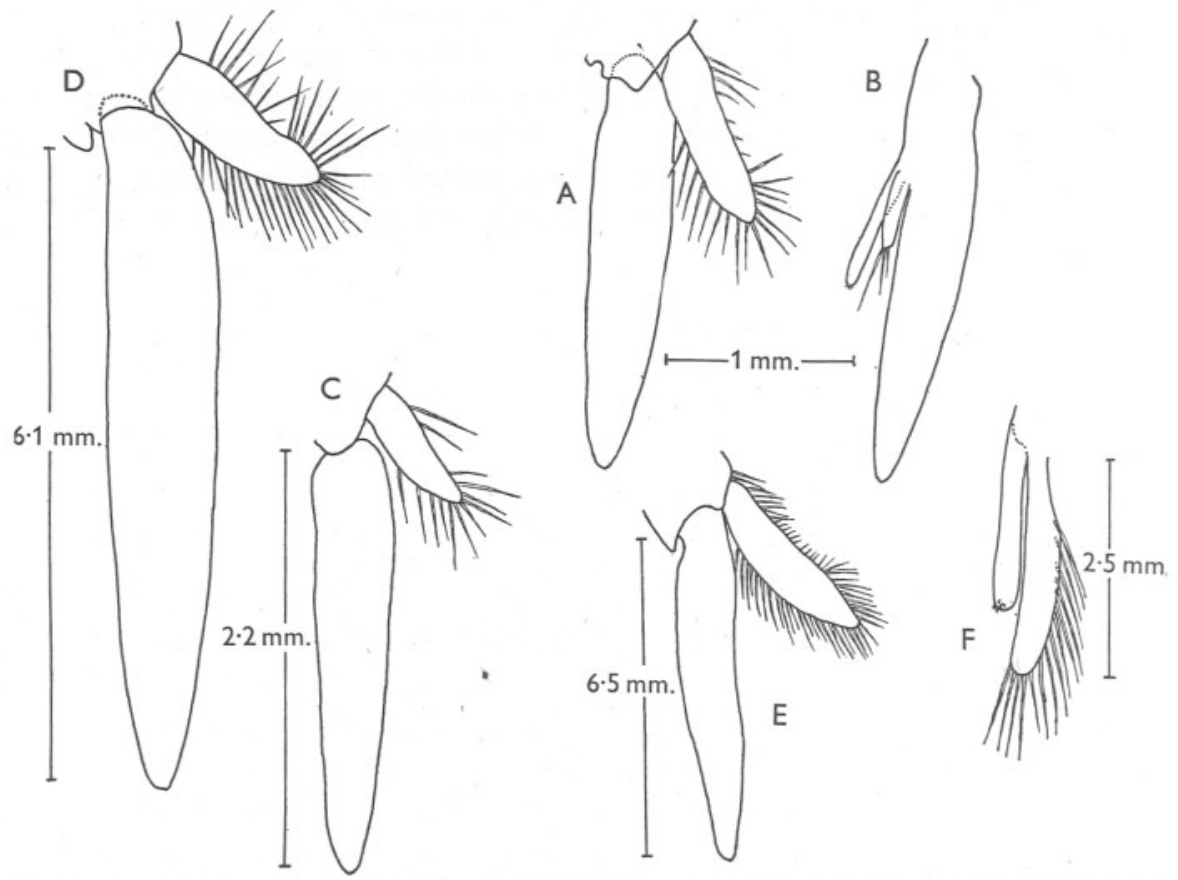

Fig. 2. Leander serratus. Secondary sex characters. A, Ist pleopod of immature $\hat{\sigma}(23 \mathrm{~mm}$.). B, setose appendix masculina of the second pleopod of the same. C, Ist pleopod of immature $+\left(24 \mathrm{~mm}\right.$.). D, Ist pleopod of mature $\$\left(68 \mathrm{~mm}\right.$.). E, Ist pleopod of mature $\sigma^{*}$ (69 mm.). F, appendix masculina of the same. In D and $\mathrm{E}$ the inner branch (with setae) has been drawn the same length as in A to show the difference in proportions.

Over a length of $2.5 \mathrm{~cm}$. the males can be distinguished from the females by the shape of the appendix interna of the first pleopod, and by the presence of an appendix masculina on the second pleopod (Fig. 2), these being the normal secondary sex characters. In case some males developed at a slower rate, sexing was not attempted for specimens below $3 \mathrm{~cm}$. in length. This limit had the additional advantages in that it allowed sexing to be done by eye, instead of with a binocular microscope, and also made the stramin net unnecessary 
since it was difficult for a $3 \mathrm{~cm}$. prawn to escape through the $\frac{1}{2}$ in. mesh of the hand-net.

Collections in September and October 1950 are illustrated in Fig. 3. Growth is shown by the shift of the peak from approximately 3.75 to $4.75 \mathrm{~cm}$. or over. There appears to be no differential growth rate between the sexes up to this stage, although the catch from Burgh Island shows a tendency in this

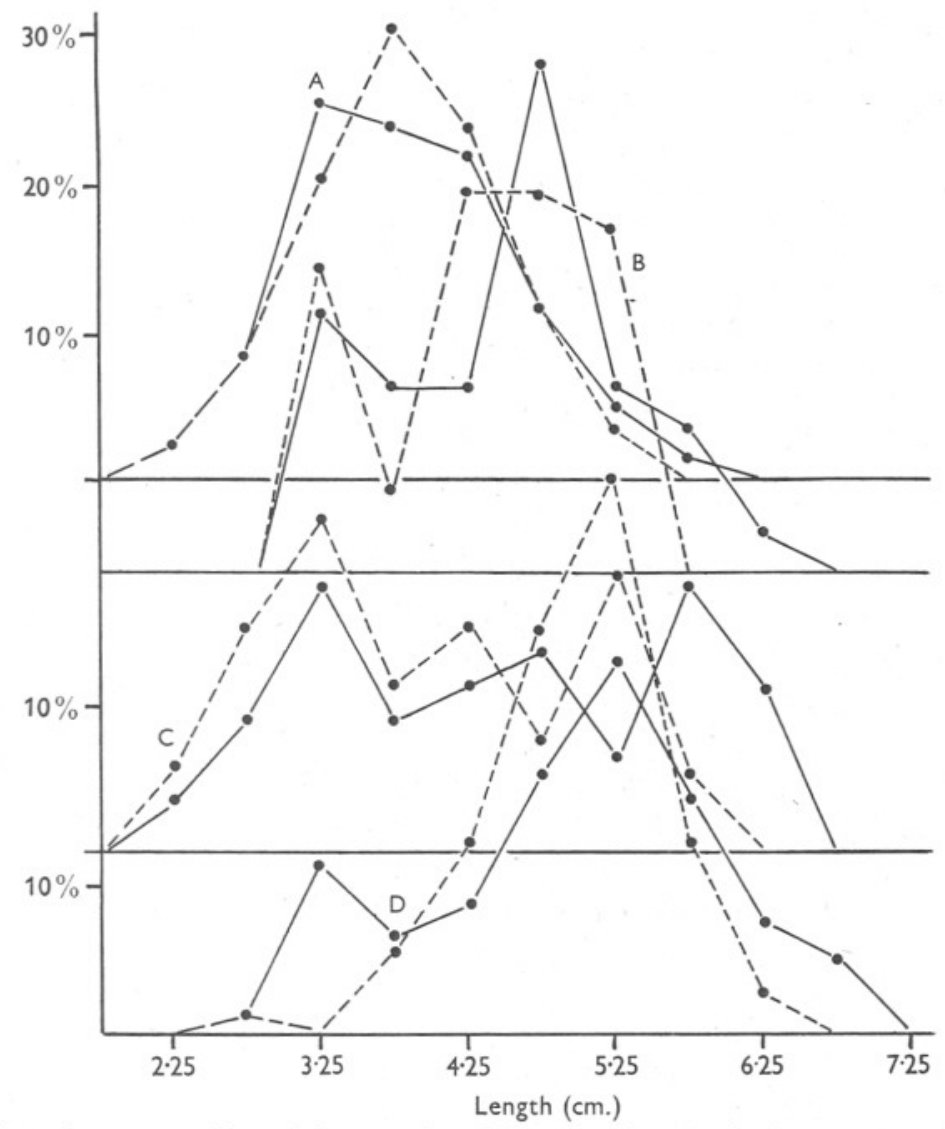

Fig. 3. Leander serratus. Length frequencies of the 1950 O-group in the autum. A, Rum Bay, I2 Sept. I950 $\left(60 \%, 60 \delta^{2}\right)$. B, Rum Bay, 9 Oct. I950 (4I $\left.+39 \hat{o}^{\hat{2}}\right)$. C, Burgh Island (outside Sound), I3 Oct. I950 (44 $+27 \hat{\jmath})$. D, Drake's Island, II Oct. I950 (80 $+70 \hat{\jmath})$. - , females; - - -, males.

direction. This catch is of interest, since the coast is considerably more exposed to wave action than the Sound. Growth appears to have been just as rapid as in the Sound, but there is a greater proportion of the population in the small-size groups. Possibly in the open sea the chances of the larvae being swept into the littoral zone (where metamorphosis appears to take place) are smaller and therefore the period of settling prolonged. 


\section{Comparison of the 1949 and 1950 Year Groups}

The overwintering population of prawns was studied from October 1949 onwards. It was therefore necessary to delimit the I949 O-group for comparison with that of 1950 . This was not difficult for the males (Fig. 5), but as shown in Fig. 4 the females presented a more complex pattern. The first

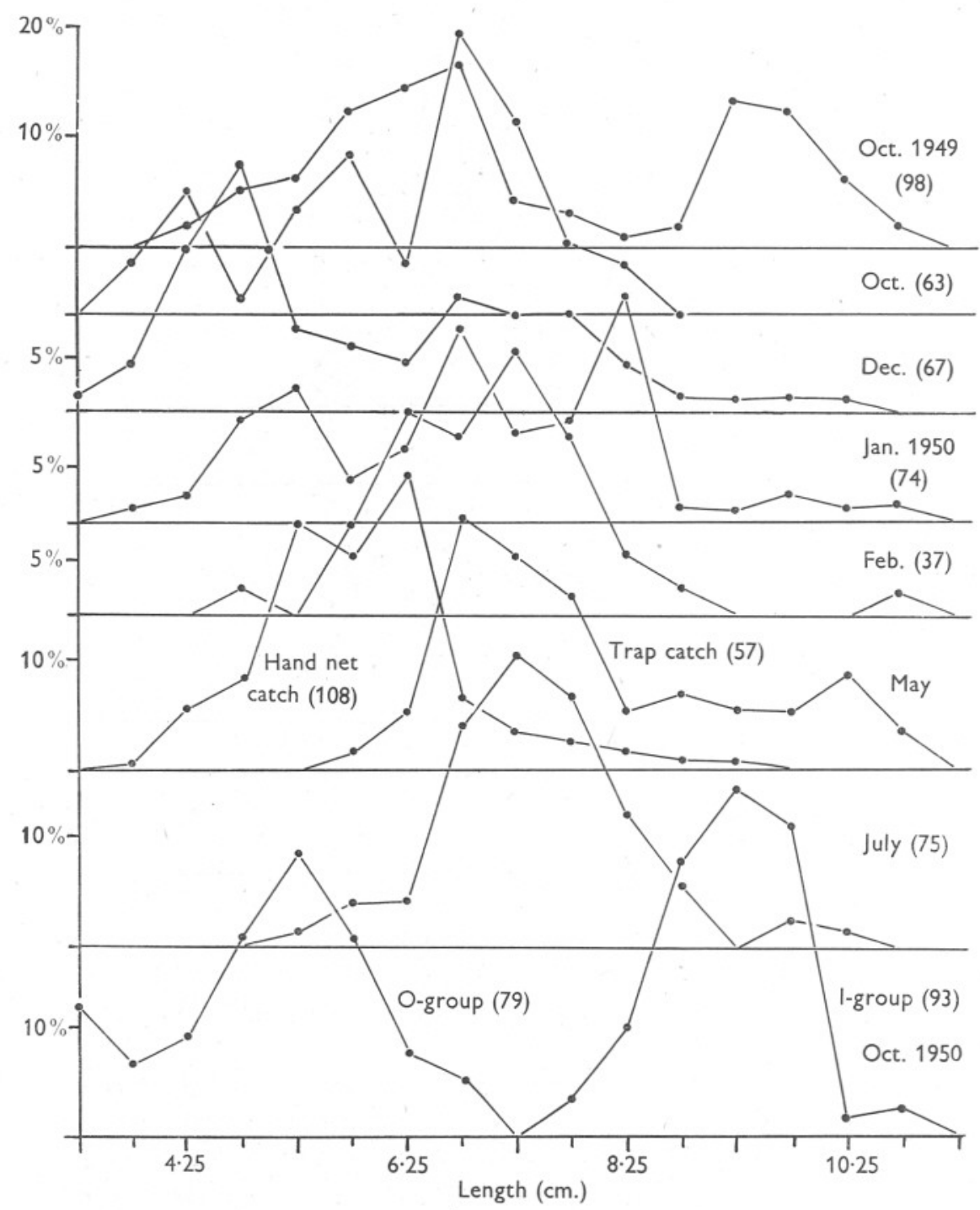

Fig. 4. Leander serratus. Length frequencies of selected catches of females, Oct. I949 to Oct. I950. 


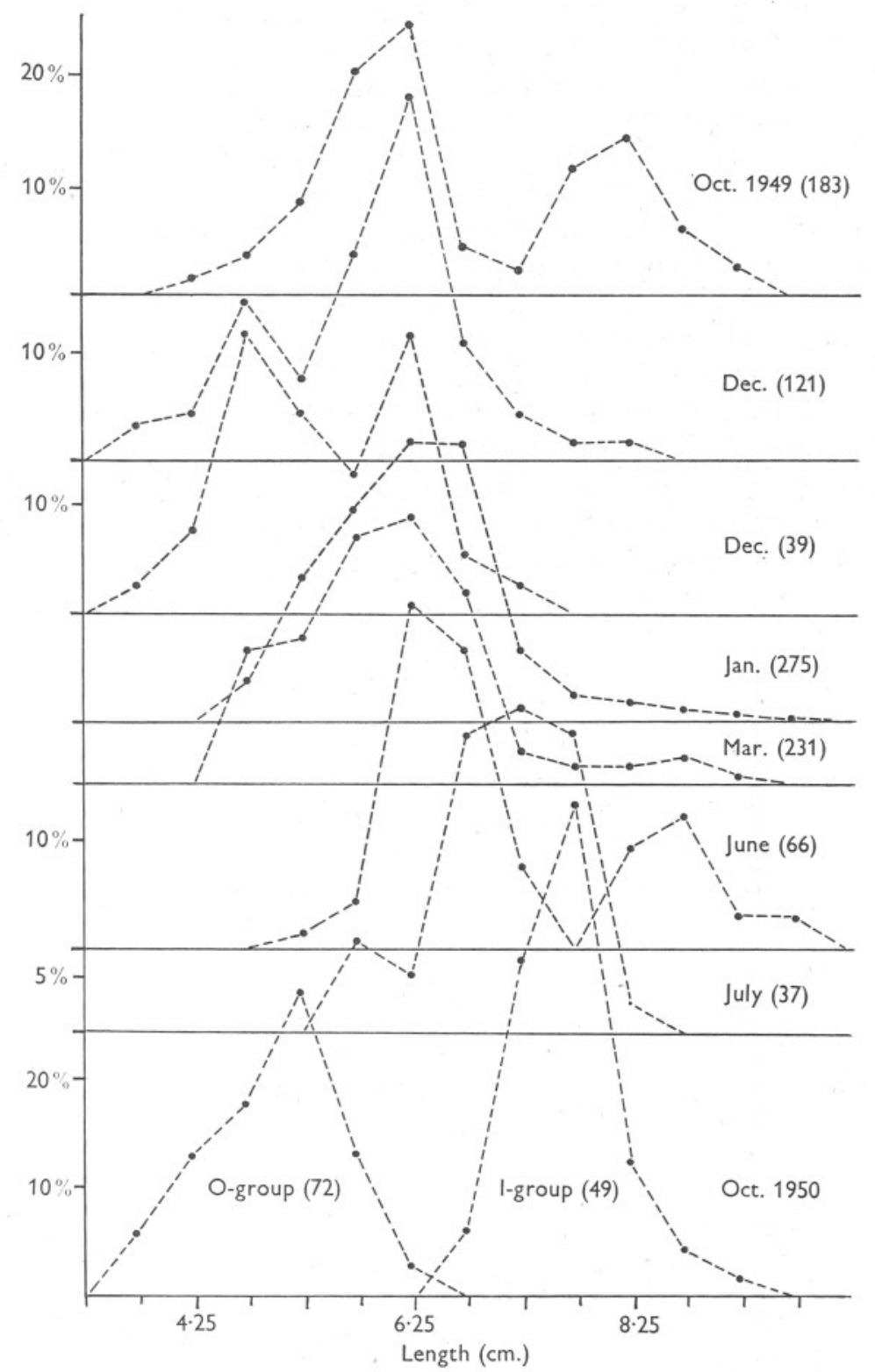

Fig. 5. Leander serratus. Length frequencies of selected catches of males, Oct. 1949 to Oct. I950. 
trawl catch (I8 October I949) shows bimodal curves for both sexes, which was a pleasantly simple picture. By December, however, with the males a small secondary peak showed up at $4.75 \mathrm{~cm}$.; while with the females the original peak at $6.25 \mathrm{~cm}$. gave place to a complex pattern with three minor peaks at approximately $4.75,6.75$ and $8.25 \mathrm{~cm}$. This population can only be analysed after a study of catches during the summer of 1950 , where it is seen that in I950 all the prawns from 4.25 to $8.25 \mathrm{~cm}$. groups shift into one peak, which clearly corresponds, although the average length is slightly smaller, to the larger peak at approximateiy $9.5 \mathrm{~cm}$. in the trawl catch from below the Hoe in October I949 (Fig. 4). Since the group with the $9.5 \mathrm{~cm}$. peak in October I950 coritains all the smallest prawns before the appearance of the r950 O-group, it must therefore have been the previous year's brood, i.e. the I949 year group. By tracing this group back to October 1949, the I949 O-group can be delimited. It appears to include all males below $7.25 \mathrm{~cm}$. and all females below $7.75 \mathrm{~cm}$. The apparent peak of females at $8.25 \mathrm{~cm}$. in some winter trawl catches is discussed later (p. 342). On this basis, Fig. 6 shows the I949 and I950 O-groups superimposed on one another. There is seen to be a

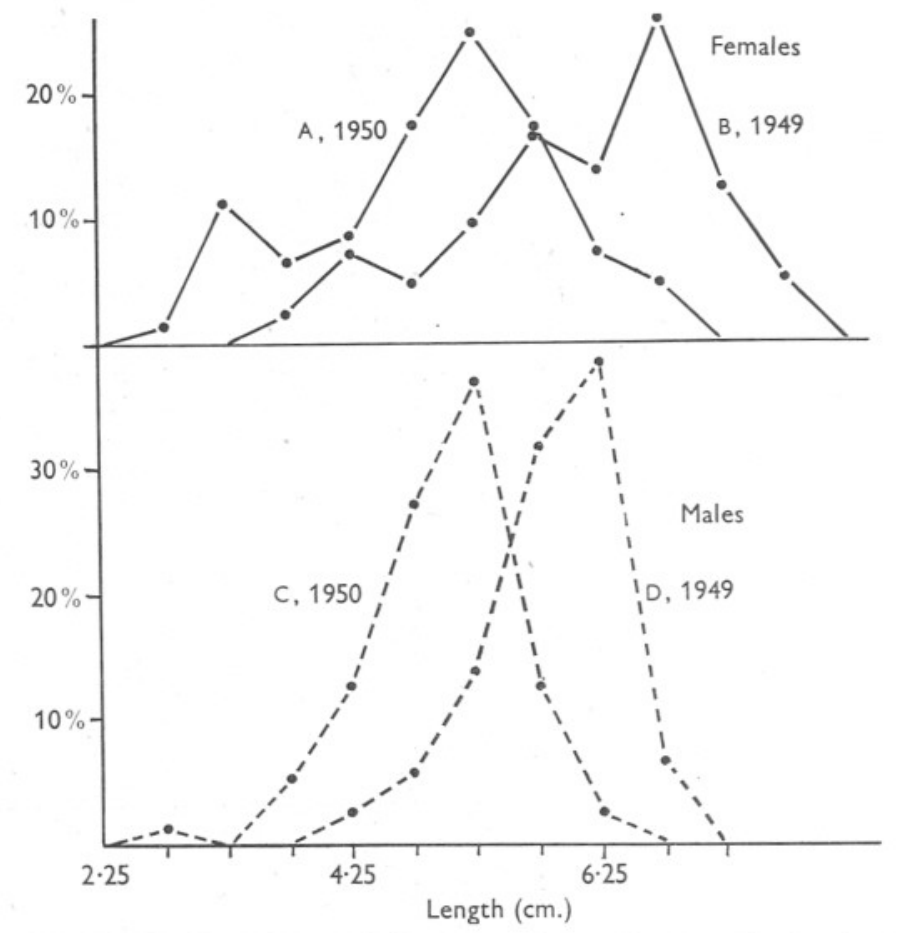

Fig. 6. Leander serratus. Comparison of the 1949 and 1950 O-groups in October of the same year. A, Drake's Island, II Oct. I950 (80). B, average of trawls off the Hoe, 2 I and I8 Oct. I949 (60) and Trevol Pier, 20 Oct. I949 (63). C, Drake's Island, I I Oct. I950 (70). D, trawl off the Hoe, I2 Oct. I949 (Ir6). 
difference of about I cm. between the peaks for both sexes, the I949 brood having clearly outgrown the largest October I950 O-group catch. The year I949 was exceptional for the warm weather during summer and autumn; whereas I950 had a much cooler summer. Extraction of the daily sea temperature readings from the bathing station on the Hoe gave the following results. The sea temperature remained above $15^{\circ} \mathrm{C}$. for 6 weeks longer in 1949 than in I950. From I July to I2 October inclusive, the average of the daily sea temperature records was $17.27^{\circ} \mathrm{C}$. in 1949 and $15.57^{\circ} \mathrm{C}$. in 1950 . Alternatively, the difference may be expressed as the cumulative (daily) excess temperatures above $15^{\circ} \mathrm{C}$., which was $231.8^{\circ} \mathrm{C}$. in 1949 and $59.66^{\circ} \mathrm{C}$. in 1950 .

The problem is therefore to ascertain whether this temperature difference is a reasonable explanation of the difference in mean lengths between the two successive O-groups. Thanks to the assistance of Mr G. M. Spooner, it was possible to calculate the temperature characteristic for growth from the data, and to compare the result with known values.

Assuming that metamorphosis took place at the beginning of July in I 949 and I950, and that the average length of the post-larva was $9 \mathrm{~mm}$. in both cases, the growth increment (for males only) during the I04 days till I2 October was $49.45 \mathrm{~mm}$. in I949 and $40.84 \mathrm{~mm}$. in I950. The average temperatures during this period were 17.27 and $15.57^{\circ} \mathrm{C}$. respectively.

The Arrhenius equation for the temperature characteristic $\mu$ is taken from Needham (I93I, p. 5I5):

$$
\frac{\mathrm{I}}{g_{1}} \div \frac{\mathrm{I}}{g_{2}}=\exp \left[\frac{1}{2} \mu\left(\frac{\mathrm{I}}{T_{1}}-\frac{\mathrm{I}}{T_{1}}\right)\right]
$$

where $g_{1}$ and $g_{2}$ are the times to reach a definite state at the high and low temperatures $T_{1}$ and $T_{2}$ expressed in degrees absolute. In this case the reciprocals of the growth increments during the same period of time are substituted for $g_{1}$ and $g_{2}$ (assuming uniform growth for the period).

We then have:

$$
\begin{aligned}
& \frac{\mathrm{I}}{40 \cdot 84} \div \frac{\mathrm{I}}{49 \cdot 45}=\exp \left[\frac{1}{2} \mu\left(\frac{\mathrm{I}}{288 \cdot 57}-\frac{\mathrm{I}}{290 \cdot 27}\right)\right], \\
& \text { therefore } \quad \frac{49 \cdot 45}{40 \cdot 84}=\exp \left[\frac{1}{2} \mu(0 \cdot 000020)\right] \text {, } \\
& =\exp \left[\mu \times \mathrm{IO}^{-5}\right], \\
& \log \left(\frac{49 \cdot 45}{4 \mathrm{C} \cdot 84}\right)=\mu \times \frac{10^{-5}}{2 \cdot 303}, \\
& \mu=2 \cdot 303 \times 10^{5} \times \log \left(\frac{49 \cdot 45}{40 \cdot 84}\right) \\
& =\mathrm{I} 9, \mathrm{I} 20 \text {. }
\end{aligned}
$$

Growth increments for the females were $40.74 \mathrm{~mm}$. in I950 and $52.09 \mathrm{~mm}$. in 1949 from which $\mu$ is found to be 24,580 . The data for the females is less reliable, however, since it is based on smaller numbers. 
From the data shown by Needham (I93I, fig. 84), it may be seen that for growth processes a large proportion of the known values of $\mu$ lie between I7 and 2 I,000 with a smaller mode of 27,000 , so that the calculated value appears quite reasonable, bearing in mind the scanty nature of the information. Therefore it may be concluded that the difference in mean size between the two year groups was most probably a temperature effect, though it is impossible to tell whether this might be direct or indirect.

\section{Later Growth of the Males}

The I949 year group. The form of the 1949 male population remained fairly constant throughout the winter with a clear peak at $6.25 \mathrm{~cm}$. In March and April I950 there was an increase in the $5.25 \mathrm{~cm}$. group to form a shoulder on the main peak which probably represented the secondary peak at $4.75 \mathrm{~cm}$. shown in the previous December catches (Fig. 5). By June these had grown a little and merged into the main peak. From July to October the graphs show steady growth until the now one-year-old group reached $7 \cdot 75 \mathrm{~cm}$. This corresponds to the peak at $8 \cdot 25 \mathrm{~cm}$. found in the trawl catches during October 1949. Again the discrepancy may be explained as a temperature effect, since it would be expected that with larger slower-growing prawns the difference would be less than with the O-group.

The 1948 year group. After October 1949 there was no further indication of more than occasional I-year-olds in the catches, until the hoop-net catch from Paignton in February which shows (Fig. 7) a clear peak with the same mean length of approximately $8.25 \mathrm{~cm}$. Again, in the spring this group was not taken by the trawls but it reappeared in the trap catches during May. In June the mean had risen slightly to about $8.75 \mathrm{~cm}$. Subsequently, during July and August, trap catches were poor and there was no further sign of these prawns continuing their third year of existence.

\section{Later Growth of the Females}

The I949 year group. In separating the I949 O-group from the autumn and winter trawl catches the complexity of the length distributions has already been noted. If we compare the I 949 October catches with those of January I950 (Fig. 4), we see that a peak at $8.25 \mathrm{~cm}$. has appeared in January, which at first sight might be attributed to growth of the 6.75 and $7.25 \mathrm{~cm}$. groups. Although it showed up in three different catches from the Sound, this peak disappeared from the catches after January, and its origin must therefore remain obscure. By February the trawl catches having lost the $8.25 \mathrm{~cm}$. peak show a pattern which would be expected if there had been little growth since October (Fig. 8). The hoop-net catch from Paignton gave a similar peak though with a slightly higher mean length. This was probably due to the smaller size groups tending to be restricted to the shallowest water, whereas the hoop-nets were shot chiefly around the 5-fathom line. In March and April only the 
smaller size groups are well represented in the trawl catches, presumably owing to the larger prawns migrating inshore first. It was not until May, when catches were made with baited traps as well as by hand-net, that a clear picture could be obtained. The population now becomes sharply divided, with the hand-net taking nearly all those below $6.5 \mathrm{~cm}$. and the traps most of those above $6.5 \mathrm{~cm}$., as shown in Fig. 4. Fig. 8B represents the mean of these two

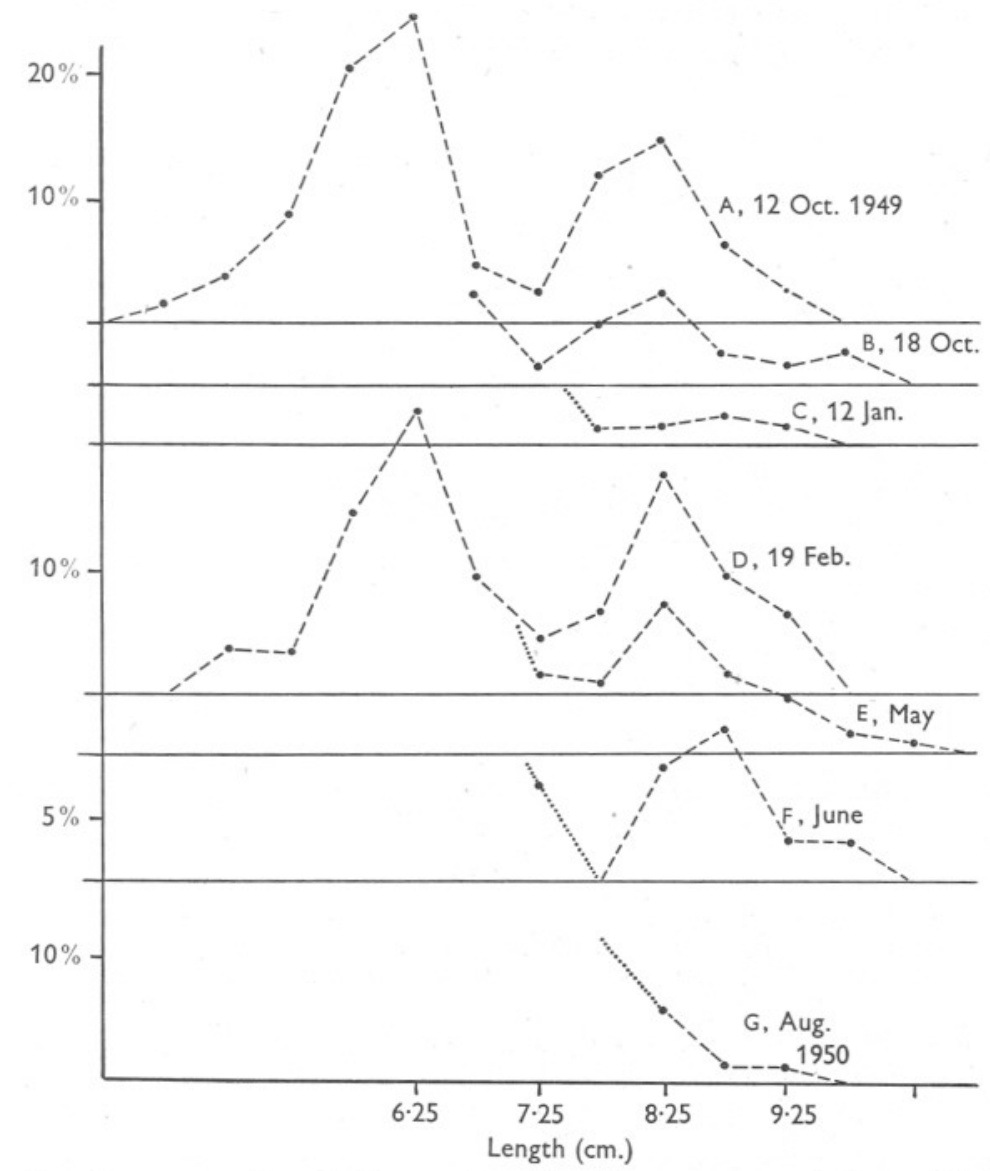

Fig. 7. Leander serratus. Length frequencies of 1948-year-group males (except in October and February the I949 year group has been omitted). Samples taken by: A, trawl (67); $\mathrm{B}$, trawl (I6); C, trawl (I8); D, hoop-nets (27), Paignton; E, traps (6I); F, traps (I8); $\mathrm{F}$, hand-net (7).

catches, giving a widely spread peak at $6.75 \mathrm{~cm}$. The length frequencies of the I949 year group in the trap catches were scaled up to percentages, and these were averaged with percentages in the hand-net catch, so as to eliminate the effect of this second peak in the trap catch. It was not possible to estimate the relative abundance of these two populations, and therefore this curve is by no 
means an accurate representation of the whole one-year-old group. It does, however, show the wide spread caused by the long breeding season and serves as a basis for comparison with later catches. A similar combined catch taken 3 weeks later (Fig. 8B) shows a peak at $7 \cdot 25 \mathrm{~cm}$. implying an average growth of half a centimetre. The difference between the means is actually $0.4 \mathrm{I} \mathrm{cm}$. After July the trap catches were poor, possibly due to the population moving closer inshore, so that growth can only be estimated from the hand-net catches (Fig. I0). These may at first be affected by an intermingling of the outer

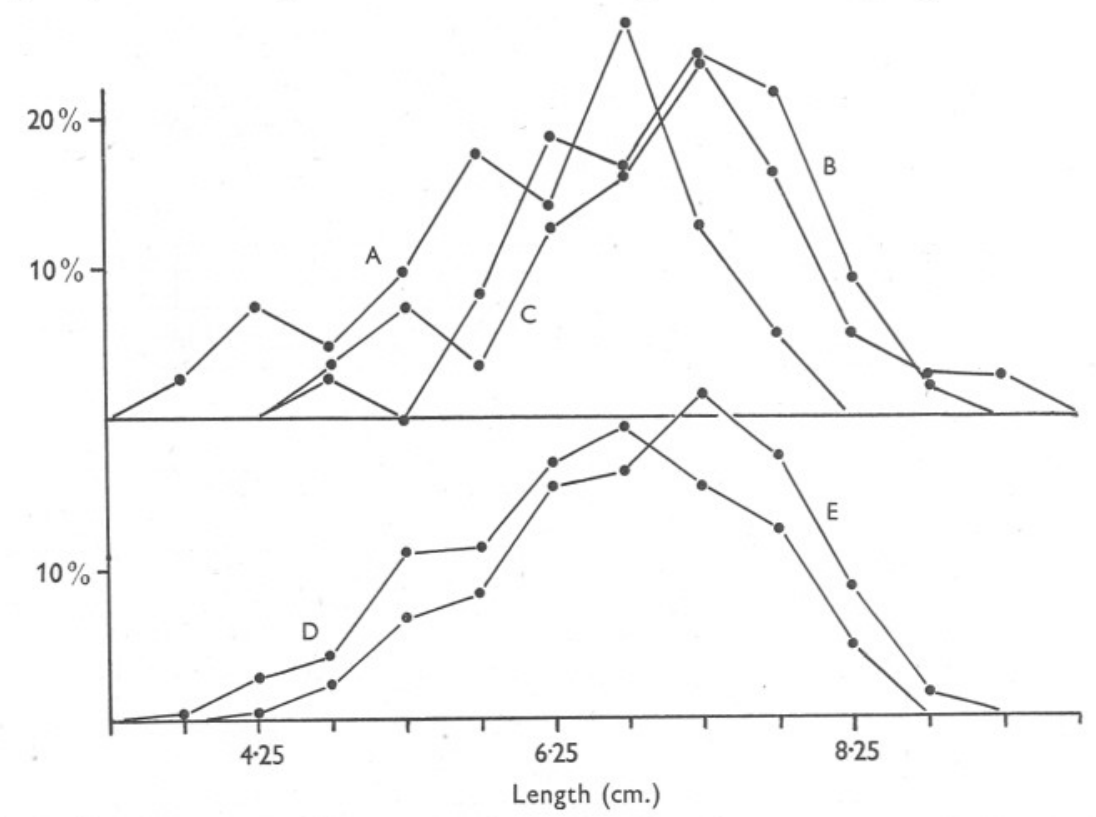

Fig. 8. Leander serratus. Above, comparison of catches of 1949 year group in October and February: A, October, trawl (I23); B, February, trawl (37); C, February, hoop-nets. Below, two combined trap and hand-net catches. D, May 3 I ; E, 24 and 27 June.

population, but the combined trap and hand-net catch (ratio 43-47) on 28 July (Fig. 9) is almost identical with the previous day's hand-net catch, the means being 7.44 and $7.35 \mathrm{~cm}$. respectively. The hand-net catches may therefore be considered representative of the whole population, for by this time the places where the larger prawns tended to congregate had been discovered. Fig. Io shows hand-net catches at approximately monthly intervals, chiefly from Rum Bay. By October there appears to have been fairly rapid growth so that the peak has moved up to $9.25 \mathrm{~cm}$., slightly below that of the I948 year group in October 1949 (Fig. II), as would be expected.

The I948 year group. After October I949 the largest size groups (8.75I0. $75 \mathrm{~cm}$.) which can now be ascribed to the 1948 year group, disappeared from the trawl catches. During February 1950, however, occasional catches of 
prawns were made by the research ships Sula and Sabella, chiefly after gales. These were composed of very large prawns, whose distribution curves showed peaks in the region of $10.25 \mathrm{~cm}$.

A similar-sized catch was taken with lobster pots from an offshore ground near Dartmouth (see p. 354) and appeared to be representative of a fairly large

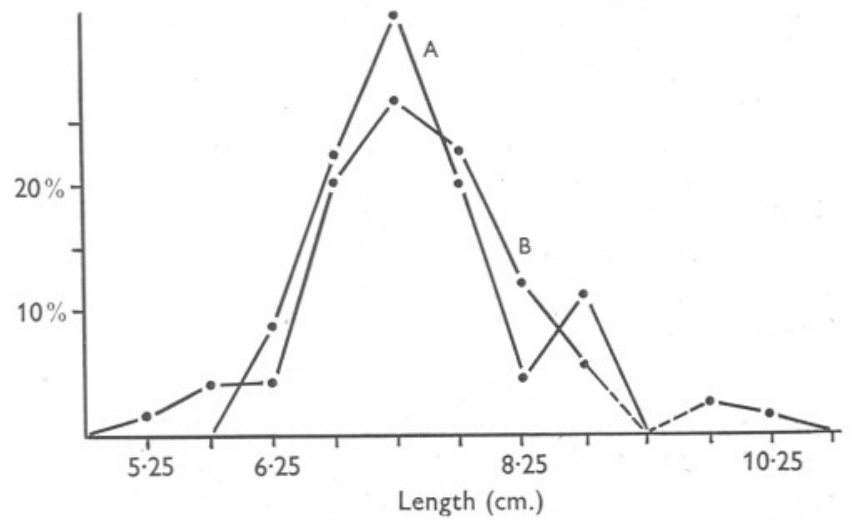

Fig. 9. Leander serratus. One-year-old females in July 1950 (see p. 344). A, hand net, 27 July. B, combined trap and hand-net catches, 28 July.

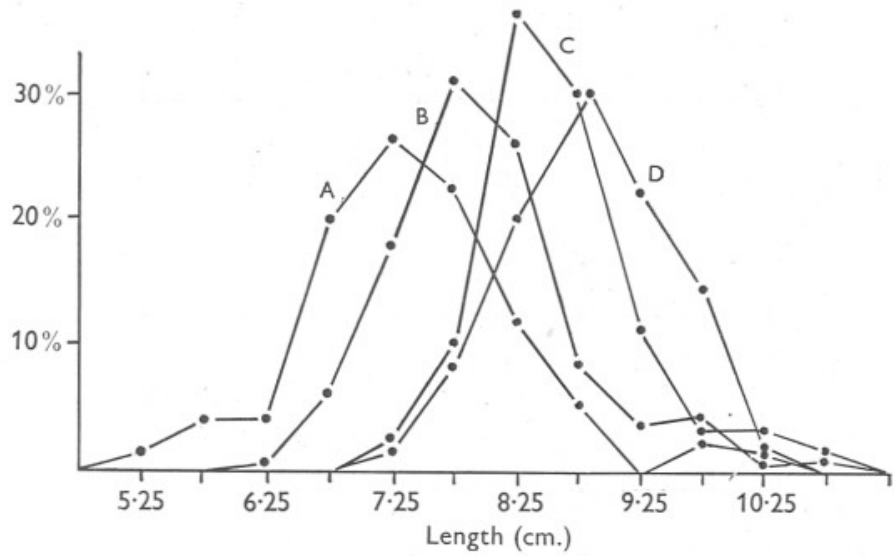

Fig. Io. Leander serratus. Length frequencies of the 1949 year group, July to October 1950. A, Rum Bay, July (75); B, Rum Bay, August (I6I); C, Rum Bay, September (59); $D$, average of catches from Drake's Island and River Yealm mouth, October (I68).

population. The distribution curve presents a clear 'skew' pattern (Fig. II, February), implying a selection against the smaller size groups. It is therefore likely that there is no significant difference between this group and that caught in October (Fig. II), so that' the bulk of these winter catches were probably composed of the 1948 year group. However, prawns above II cm. in length 
were almost totally absent from Sound catches and may therefore have been older or have grown more rapidly than the inshore population.

This group also appeared during February in the hoop-net catch from Paignton, but in a rather smaller proportion, not forming a clearly defined peak.

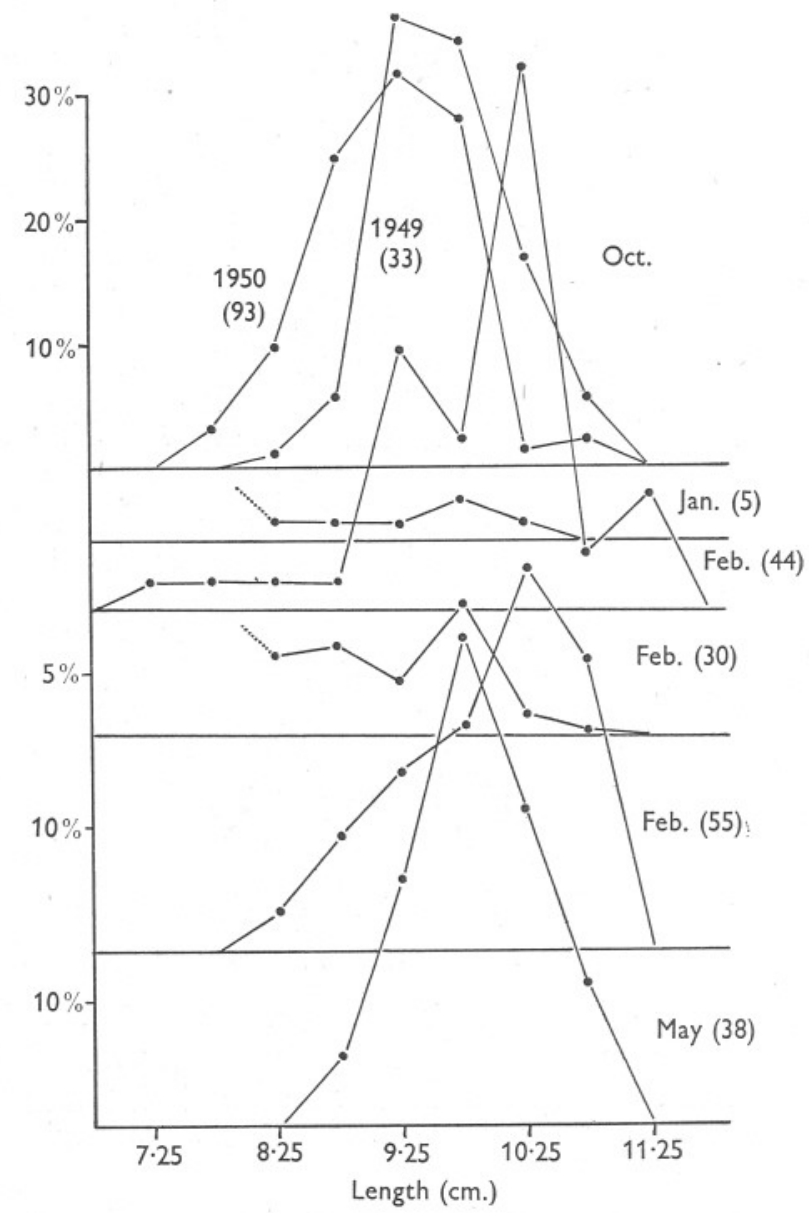

Fig. I I. Leander serratus. Length frequencies of I-year-old females (see p. 345). The October and May figures are from fractions of catches scaled up to roo. October and January catches trawled in the Sound. February catches trawled in 20 fathoms (above), hoop-nets in 4 fathoms (centre) and lobster pots in II fathoms (below). May catch from traps inside Sound.

During spring and early summer the group shows up clearly in the trap catches (Fig. II). There is no sign of any growth during the winter, the peak remaining at $9.75 \mathrm{~cm}$. as in October. After July the trap catches declined and only occasional specimens were taken on the shore, therefore there was probably 


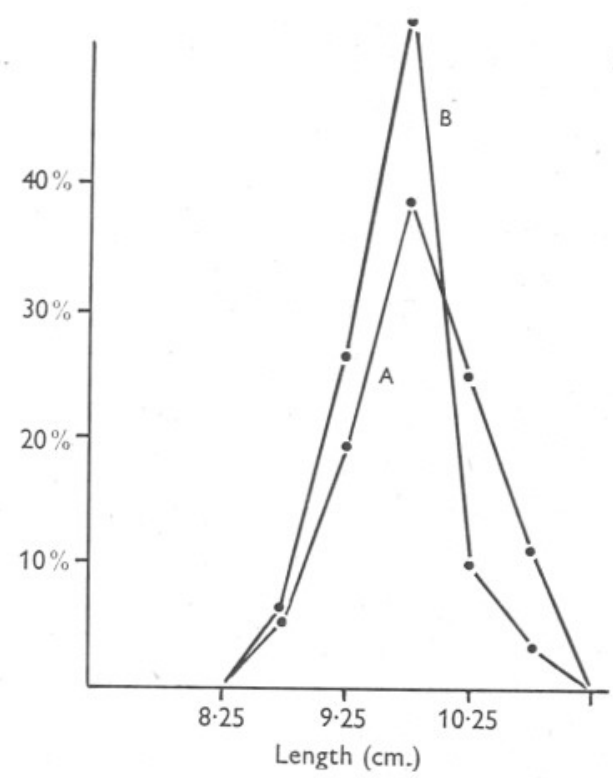

Fig. I2. Leander serratus. Comparison of trap catches of I948 year group on (A) I9 and 3 I May I950 (36) and (B) 23 and 24 June I950 (60), showing decline from $37 \%$ over ro cm. length in May to only ro \% in June.

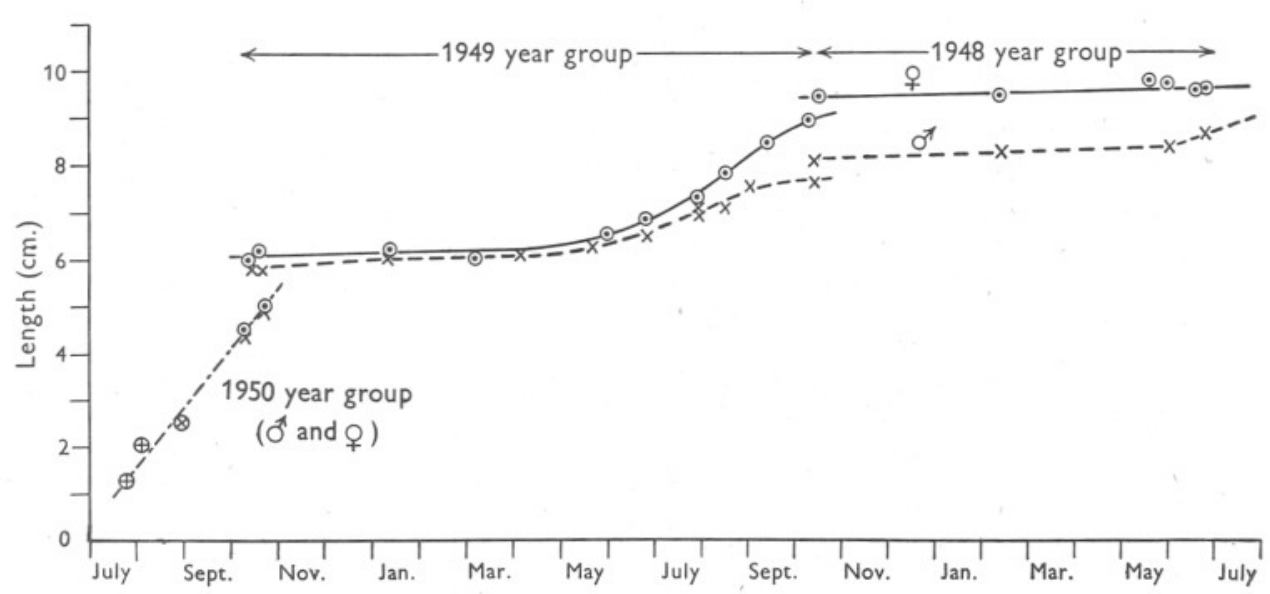

Fig. 13. Mean lengths of the various samples of three year groups, forming an approximate growth curve. 
a considerable natural mortality at this time which may be related to the hatching of the last brood. Comparison of trap catches in May with those of June (Fig. I2), reveals a decline in the percentages of the two largest size groups from $37 \%$ over ro cm. in length in May to only 10 \% a month later. This also appears to show a natural mortality, since there is no reason to presuppose any migration during this period.

The growth data have been summarized in Fig. I3 by plotting the mean lengths of the different year groups from October I949 to October I950. These results differ considerably from the conclusions on age and growth of this species reached by Nouvel and Van Rysselberge (I937), based on measurements of growth increments after moulting. At Plymouth there was little growth during the winter, though moulting continued. This may well be the case at Roscoff, since the sea-surface temperatures do not appear to differ by more than $I^{\circ} \mathrm{C}$. (Lumby, I935). Nouvel and van Rysselberge attributed the greater size attained by the females to an extra year's growth, but at least at Plymouth this is incorrect since the males' growth rate is less.

Sollaud (I9I6) had previously noted both the suppression of growth in the winter and the slower growth rate of the males, so that it is difficult to understand why Nouvel and van Rysselberge apparently took no account of his work. Sollaud, himself, gives a few figures for the growth of female L. serratus which he states live for 5 or 6 years. But unfortunately he gives no details of the data on which his conclusions were based.

Owing to variations in the distribution of the size groups no reliable estimates of mortality can be made.

\section{BREEDING}

\section{Males}

Little attention was paid to breeding biology of the male prawns owing to its relative uniformity among the Natantia. Maturity is reached at an early stage, since during December a ripe female prawn in a tank with several small males in the $40-44 \mathrm{~mm}$. group (i.e. 6-7 months old) became berried, showing that one of these had become capable of successful fertilization.

\section{Females}

Data on the breeding of female prawns is summarized in Fig. I4; grouping by length is justified since it has been shown that there was little growth during the winter, while towards the end of the breeding season growth shown in the graphs can only be due to those females which have hatched their eggs. In Fig. I4 the I949 year group is divided into four I cm. groups up to $8.4 \mathrm{~cm}$., the I948 year group being represented by the $8 \cdot 5-9 \cdot 4$ and $9 \cdot 5-10 \cdot 4 \mathrm{~cm}$. groups. Only the two smallest groups show non-breeding or neuter individuals throughout the whole period. In the $4 \cdot 5-5 \cdot 4 \mathrm{~cm}$. group only one berried female was taken: therefore those which possessed a maturing ovary probably 


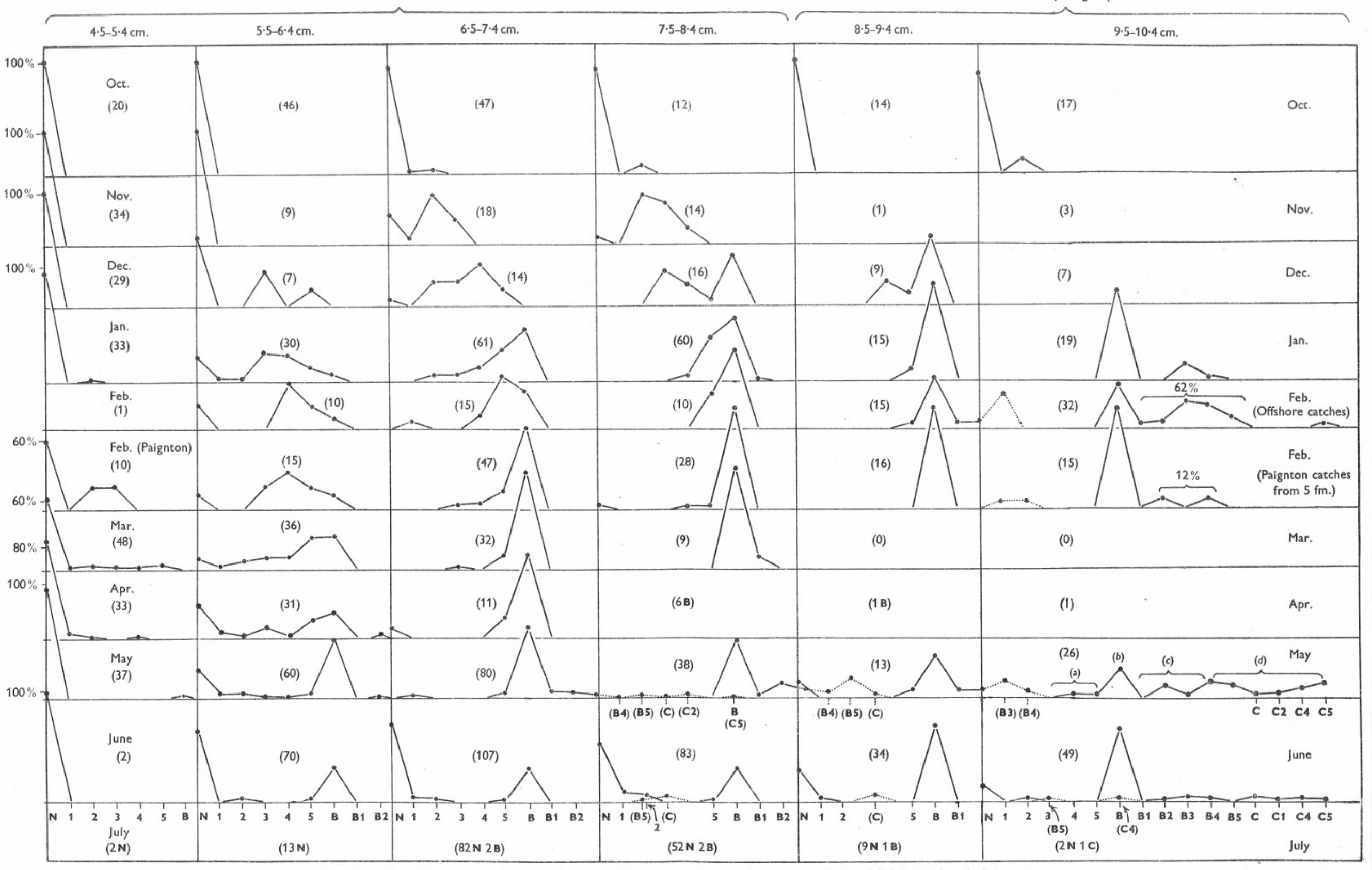

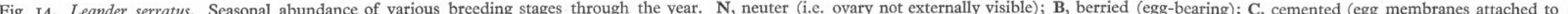

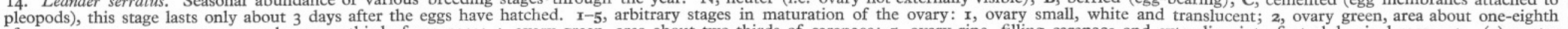

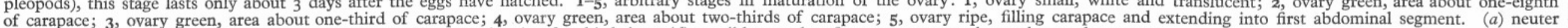
intermoult after hatching first brood; $(b)$ 2nd brood; $(c)$ ovary ripening for third time; $(d)$ possibly very late first spawners or advanced second spawners. 
grew sufficiently during March and April to be included in the next larger group. The next three sections $(5 \cdot 5-8 \cdot 4 \mathrm{~cm}$. inclusive) show that with increase in size spawning takes place earlier: February for the $5.5-6.4 \mathrm{~cm}$. group; January for the $6 \cdot 5-7 \cdot 4 \mathrm{~cm}$. group; and December for the $7 \cdot 7-8 \cdot 4 \mathrm{~cm}$. group. Correlated with this is the increase in the proportion which produce a second brood.

\section{The Period of Egg-Carriage}

The approximate time of spawning may be deduced from Fig. I4 as the point where the majority of any one particular group change from showing ripe or ripening ovaries to the 'berried' condition. The end of the period of egg-carriage is more difficult to ascertain since, unless the ovary ripens again for a second brood, the animal may hatch its eggs and moult, remaining 'cemented' for only 2-4 days. Thus only small numbers of cemented females may be expected. Notes were kept of the number of females whose eggs were nearly hatching as shown by the transparency of the eggs, all the yolk having been used up, and by the conspicuous eyes of the embryos. During the first intermoult period after hatching the eggs, the length of the epimera or side plates of the abdomen was considerably greater than that of non-breeding females. This gave a method of separating those of the $5 \cdot 5-6 \cdot 4 \mathrm{~cm}$. group which had just finished breeding in June, from non-breeding individuals. The period of egg-carriage for the majority of the $5 \cdot 5-6 \cdot 4 \mathrm{~cm}$. group is thus considered to have lasted from the beginning of March till the end of June, or approximately 4 months; bearing in mind that in the spring the smaller prawns were growing and some may have been included in this group. Similarly, for the $6 \cdot 5-7 \cdot 4 \mathrm{~cm}$. group about $85 \%$ spawned in January and February, whilst the most advanced hatched their eggs in May.

Thus for both these groups the period of egg-carriage appears to have been about 4 months. The $7 \cdot 5-8 \cdot 4 \mathrm{~cm}$. group spawned chiefly in December and January, but in April, when some hatching might have been expected, only six specimens were taken. Thus the length of egg-carriage cannot be estimated, for by May some may have spawned a second time.

The two largest size groups comprising prawns of 8.5-9.4 and 9.5-10.4 cm. (including the few specimens which exceeded $10.4 \mathrm{~cm}$.) could not, unfortunately, be caught throughout the whole season, so that results are incomplete. Spawning probably began in November, since the few specimens obtained in December were almost all berried. Information also came from lobster fishermen that they had first taken berried prawns about 7 November. Another lobster pot catch from the same area was examined on I8 February when about $3 \%$ had eggs ready to hatch, and altogether $90 \%$ showed ovaries ripening for a second brood. From the state of the eggs it seemed unlikely that much hatching would have taken place before the beginning of March. Here again the period of egg-carriage appeared to be about 4 months. Another February sample of these two size groups was obtained with hoop-nets at Paignton in 
shallow water (less than 5 fathoms), only I2.I \% of which contained ripening ovaries. Development appears therefore to be retarded under inshore conditions, possibly associated with slightly lower temperatures. In March and April no catches were obtained, and it was not until May that the traps supplied reasonable samples. Referring to Fig. I4, the patterns shown in May and June are rather complex, which in part may be due to a mixture of the stock after those from the deeper water had migrated inshore. The non-berried females with a ripening ovary are clearly passing through a neuter intermoult period after hatching their first brood; however, berried females up to stage 3 would be expected to be carrying their second brood of eggs, with the most advanced showing signs of a forthcoming third spawning. Since it has been shown that there was little hatching in February, the berried females in stage 5 in May and the cemented females could not be hatching their second brood and may possibly represent that part of the population which overwintered inshore lagging behind the offshore population by more than a month. It is unlikely that the difference in temperature between 5 and $\mathrm{I} 5$ fathoms is more than $\mathrm{I}^{\circ} \mathrm{C}$. (Dr H. W. Harvey, personal communication) which would account for a lag of only $2 \frac{1}{2}$ weeks, taking $\mu$ for development as 20,000 (Needham, I93I, p. 52I). Therefore other factors are probably involved. One possibility is that the maturation of the ovary is connected with the offshore movement, so that those whose ovaries are slower in development have in some way less tendency to move offshore.

During June the appearance of neuter females marked the end of spawning for 28 and $14 \%$ in the $8 \cdot 5-9.4$ and $9 \cdot 5-10.4 \mathrm{~cm}$. groups respectively. In July the trap catches declined and contained only occasional non-breeding members of these two largest groups. Possibly many died after hatching their eggs, but since Lebour (1947) found larvae in September and October in I944, a few of these may survive, perhaps hidden away in slightly deeper water.

Sollaud (I9I6) stated that the females of L. serratus did not mature until the end of their second summer, and some not until the spring of their third year. This would imply that on the French coast this species takes very much longer to mature. But, as with his statements on the age and growth, no hint is given of the data on which he based them.

The production of eggs. Only a few egg counts were undertaken to estimate numbers of eggs produced by the largest and smallest females, since Höglund's

Table I. Number of Eggs Produced by SMall and LaRge PraWNS

$\begin{array}{cccc}\begin{array}{c}\text { Length } \\ (\mathrm{cm} .)\end{array} & \begin{array}{c}\text { No. } \\ \text { eggs }\end{array} & \begin{array}{c}\text { Length } \\ (\mathrm{cm} .)\end{array} & \begin{array}{c}\text { No. } \\ \text { eggs }\end{array} \\ 6 \cdot 2 & 1523 & 9 \cdot 3 & 3887 \\ 6 \cdot 8 & 2106 & 9 \cdot 6 & 3150 \\ 7 \cdot 0 & 1628 & 10 \cdot 4 & 3859 \\ 7 \cdot 1 & 1989 & 10 \cdot 5 & 4282\end{array}$


extensive egg counts on L. squilla have shown a logarithmic relationship between body size and number of eggs, dependent presumably on the increase in volume of the carapace.

\section{Distribution AND Migrations}

The geographical range of $L$. serratus extends from Britain to the Mediterranean (Kemp, I9I0), with the region of the Wash marking its northern limit.

\section{Metamorphosis of the Larvae}

No systematic collection of larvae from the plankton was attempted. Instead, watch was kept for the post-larval and young stages. Trawling with a stramin net lashed to the cod-end of a $6 \mathrm{ft}$. beam trawl worked from the Gammarus was carried out in the Sound at the end of May in depths of 4-5 fathoms, fairly close to the rocks. No young prawns were taken. Agassiz trawl catches during June from depths of IO-20 fathoms were also examined without success. Post-larval stages, together with late-stage larvae, were first obtained from pools at or above mid-tide level in July. Sollaud (I9I6) had previously noted this on the French coast. It was shown while analysing these catches (Fig. I, C, D) that the smallest stages were virtually absent lower down on the shore at about low-water springs. Since settlement was almost certainly still going on at that time ( 3 August) it seemed that metamorphosis usually occurred high up in the littoral zone. At first sight it might appear that the larvae, which are fairly widely distributed throughout coastal water, since they have been recorded from near the Eddystone (Russell, I927) where no prawns are taken by the lobster fishermen, would have to perform a definite migration to reach the shore. But the tidal streams running to and fro along the coast probably set up eddies around headlands and other obstacles sufficient to sweep many larvae inshore at one time or another. It might be possible for the larvae once in the right zone to maintain their position and so avoid being swept away before metamorphosis.

In this respect the work of Sollaud (I923) is of interest. He found, at Roscoff, that laboratory-reared larvae usually had eight stages or moults, but that larvae from townettings almost always metamorphosed at a size similar to his fifth stage. Gurney (I924) drew attention to these facts, but considered the extra stages anomalies associated with the artificial conditions. It seems, however, more reasonable to assume that this is another instance of the capacity of many larvae to postpone metamorphosis until they find suitable conditions.

\section{Distribution of the O-Group}

Autumn and winter. From July until the end of October the young O-group prawns remained abundant on the shore. Towards the end of October they 
became less numerous and after the beginning of November very few could be taken in either 1949 or 1950. At Trevol pier where conditions, though estuarine, were very sheltered, the larger prawns disappeared in October, but some of those in the smallest size groups remained till the end of November.

Throughout the winter (1949-50) the males of the 1949 year group, 5-7 cm. long, formed the bulk of the trawl catches in the Sound. The best catches were obtained from 'White Patch' area, and from inside the Breakwater, in depths of 4-5 fathoms. The smaller members of this group showed up in the trawls from Mount Batten (shallow water I-2 fathoms and rocky bottom) as a separate peak, which did not appear with the rest of the trawl catches in slightly deeper water and on softer bottoms.

Perhaps the most notable feature of the winter catches was the relative scarcity of the females. In catches from 'White Patch' and the Breakwater the sex ratio was between three and four males to one female; whereas it will be shown that during the summer when the whole population was close inshore there was a slight majority of females. Therefore it seems probable that during the winter the females, many of which were berried, tended to remain in the greater seclusion of the rocks. This view was supported by the result of the hoop-net catch at Paignton (on rocky bottom) during February when the sex ratio was approximately one male to two females. Poulsen (I946) gave a similar interpretation to the sex ratios obtained with Nephrops norvegicus. Conditions at Paignton differed from Plymouth in that the rocks were fringed by fairly clean sand, and sheltered from the south-west. Trawls were made close to the rocks but without taking any prawns. There was thus very little offshore migration at Paignton; the only difference between summer and winter distribution being that part of the population spread into the littoral zone in summer, but not in winter or spring.

On more exposed coasts where the rocks extend into deep water the prawns would doubtless move farther offshore; evidence for this was found only in the older year groups.

The only 1949 autumn catches where the females outnumbered the males were from the Tamar estuary, the results total 36 o ${ }^{7}$ a against 77 우, which, on the expectation of even numbers, would occur by chance less than one in a hundred times. However, since the males were found to penetrate well into the estuaries during the summer (1950), it appears that they tended to leave them in the autumn before the females. Lloyd \& Yonge (1947) found that Crangon vulgaris behaved in much the same way, and showed that the males were more susceptible to combined low temperature and salinity (i.e. winter conditions) than the females. Pannikar (I94I) found that in Leander serratus the osmotic pressure of the blood scarcely differed between males and neuter females, but did not apparently differentiate the sexes in studying the capacity for osmoregulation. 
Spring and summer. During March and April the majority of the females from 6.25 to $8.25 \mathrm{~cm}$. gradually disappeared from the trawl catches. Presumably they were the first to migrate inshore. Prawns were first caught with a hand-net from the shore on 3 May, and thereafter in fair quantities. Unfortunately it was not possible to correlate this with a simultaneous disappearance from the trawling grounds, but only occasional prawns were taken during several trawls in June.

In 1949 the inshore migration must have occurred much earlier, since numerous prawns were found in shore pools at Wembury at the end of March. Aplysia punctata was also abundant at this time, but only a very few appeared inshore during the spring of 1950 . Sea-surface temperatures in the Sound were almost exactly similar for the two years, as were the air temperatures. Temperature therefore cannot have been the decisive factor in the cause of these migrations.

During early summer prawns also moved up the estuaries and by July they were being fished commercially off Saltash. Percival (I929) studied the estuarine distribution of three species of Leander including L. serratus.

At Rum Bay where most of the trap catches were made, the separation of the females into two apparently distinct populations has been noted (p. 343). For instance, of the females caught on $3 \mathrm{I}$ May, the hand-net took specimens almost entirely less than $6.5 \mathrm{~cm}$., while the traps scarcely took any below this length (Fig. 4, May.) This segregation was scarcely noticeable among males, however, except that the hand-net took a much larger proportion of the $5.75 \mathrm{~cm}$. group than the traps.

\section{Distribution of the I-Year-Old Group}

After July the trap catches declined, suggesting that the whole population was close inshore, mostly within the 2 -fathom line, and at Paignton within about 4 fathoms. No change in this distribution apparently occurs until October when, according to local tradition, trawling starts (information supplied by $\mathrm{Mr}$ W. Searle). However, in the Hamoaze, especially below Saltash, trawling is sometimes successful in late August. Prawn trawling usually started near Saltash and moved downstream to Torpoint, West Muds and Drake's Island, finishing in Jennycliff Bay and inside the Breakwater. Thus there would appear to be, as the fishermen believe, a migration of the prawns away from estuarine conditions; this would be expected from the wellestablished fact that tolerance of low salinity decreases markedly with temperature in most decapods (Lloyd \& Yonge, 1947). Several trawls were made in the Hamoaze during winter with, as might be expected, negative results, but there was always the possibility that the prawns managed to hide away in places inaccessible to the trawl. Preliminary work on tagging was also undertaken to try to verify the migration, but although a method was worked out it proved impracticable to mark sufficient numbers for a reasonable chance of returns. 
In the Sound, apart from the first successful trawl in October I949 (Figs. 4 and 5, October), only very small numbers of the I-year group (9-II cm.) were taken throughout the winter. They reappeared, however, in the hoop-net catch from Paignton and the trap catches during the spring, when both sexes seemed to be restricted to a rocky bottom.

During the winter prawns were occasionally caught by Sula and Sabella on trawling grounds outside the Sound both with the otter trawl and the finer-meshed Agassiz trawl. During February, however, larger catches of up to fifty were made, chiefly after gales. These trawl catches from depths around 20 fathoms, which consisted almost entirely of large female prawns, have been discussed on p. 345. It is unlikely that they represented more than scattered offshoots from the main population. Quite large quantities of prawns were caught by lobster fishermen on various grounds between Berry Head and Start Point from November till the end of March, at a depth of about Io fathoms. Since these grounds were fished almost all the year round and no prawns were caught during the summer, there must have been an offshore winter migration. The distance between the 5- and Io-fathom lines is about half a mile in this area. The population as sampled by the lobster pots appeared to be wholly female. Out of a catch of some 200 prawns observed during an expedition with the fishermen, all were females. Several pots were partially covered with prawn netting so that if only small males had been present, some at least would have been retained. The disappearance and presumed inshore migration towards the end of March may therefore be related to the hatching of the first brood of eggs, mating, and the second spawning. The basis of the orientation necessary for even a short migration remains inexplicable.

During their third summer this group was well represented in the trap catches in the Sound until July (Fig. 4). Afterwards the catches declined and there was probably a high mortality after the second brood had been hatched.

\section{FooD}

A note of the stomach contents of Leander serratus has been given by Hunt (I925). With further study it was hoped to ascertain how the food varies at different times and in different places. Also it was of interest to see whether the feeding habits differed from those of L. squilla, since these two species overlap in their distribution on the shore.

The stomachs were removed within a day or so of collection and preserved in formalin. Most of the contents were lost if the prawns were placed in formalin while still alive. It was usually found possible to distinguish the more freshly filled stomachs from those in which the food had been subjected to a period of grinding or churning, since the latter tended to appear, under a binocular microscope, as a homogeneous mass giving off clouds of minute 
particles. Any of this type were discarded. The contents were first examined with a low-power binocular and the larger fragments or animals noted, the remainder being usually subsampled by pipetting a drop of the material on to a slide and examining under higher magnification.

\section{Notes on the Stomach Contents}

Debris. This category includes all unidentifiable finely divided material. The name is used in place of the more usual 'detritus', since it was not known whether most of the material was organic or inorganic. It was not always possible to decide whether the debris had been ingested as such or ground up in the stomach. Much churning and grinding does, in fact, take place and may be observed most readily in the smaller and more transparent prawns. Debris was more abundant in the stomach contents of trawl catches from the muddy grounds of the Sound than from elsewhere. Since it was found from aquarium observations that a muddy substratum was not ingested at random, some at least of the debris may well have been eaten accidentally with, say, algal fragments.

Algae. In all inshore catches algae usually formed a considerable part of the stomach contents. During autumn and winter the algal material found in the stomachs of trawl-caught prawns consisted chiefly of unpigmented fragments of thalloid algae which were probably derived from decaying Laminaria plants. In hand-net catches, green, thalloid and filamentous fragments were common, also occasionally brown filaments. Hoop-net and trap catches from slightly deeper water showed, as might be expected, more red forms, chiefly filamentous.

Crustaceans. Small crustaceans nearly always formed a significant proportion of the diet. Indeed the stomach contents of one off-shore trawl catch consisted almost wholly of small decapods, while the young O-group prawns very commonly fed on ostracods. Fragments of cuticle were very often found, and when ground up may have formed part of the 'debris'. It was often difficult to distinguish whether cuticle fragments of, say, a small amphipod represented parts of a 'moult' or the remains of a whole animal. When any trace of fleshy material was observed it was assumed that the whole animal had been consumed. Copepods proved particularly difficult in this respect, so that records of them may be unreliable.

Molluscs. Only one species of mollusc appeared in the stomach contents more than occasionally; this was Odostomia plicata, which Fretter \& Graham (I949) have shown to be probably ectoparasitic on Pomatoceros. These tiny gastropods were found chiefly in prawns trawled from near the Hoe. It would seem that they must be fairly common judging from the fact that one large prawn had thirty-one in its stomach. There was a surprising absence of other small gastropods which are usually abundant on algae during the summer.

Other groups. Foraminifera occurred fairly often in the stomach contents 
but rarely in significant numbers. Small polychaetes were also found occasionally, rather less frequently than might be expected. Unidentified eggs and algal spores sometimes appeared, often in considerable numbers in just one stomach out of a sample. Doubtless almost any post-larval or young stages under $2 \mathrm{~mm}$. would be taken when available.

\section{TABLe II. The Stomach CoNTENTS of LEANDER SQUILLA AND} O-Group L. SERRATUS TAKEN From the SAME Pool

\begin{tabular}{|c|c|c|c|c|c|c|c|c|c|c|}
\hline No. & Debris & $\begin{array}{l}\text { Filamentous } \\
\text { algae }\end{array}$ & $\begin{array}{c}\text { Thalloid } \\
\text { algae }\end{array}$ & Grit & $\begin{array}{l}\text { Cuticle } \\
\text { frag- } \\
\text { ments }\end{array}$ & $\begin{array}{l}\text { Forami- } \\
\text { nifera } \\
\text { L. squilla }\end{array}$ & Copepods & Ostracods & Mites & Miscellaneous \\
\hline I & + & ++ & .. & ++ & .. & 13 & .. & .. & .. & .. \\
\hline 2 & + & $\begin{array}{l}\text { Brown and } \\
\text { red }\end{array}$ & . & .. & + & 2 & .. & .. & . & . \\
\hline $\begin{array}{l}3 \\
4\end{array}$ & $\begin{array}{l}+++ \\
+++\end{array}$ & $\begin{array}{l}+ \\
+\end{array}$ & $\because$ & $\dddot{t}$ & 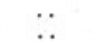 & $\begin{array}{l}7 \\
7\end{array}$ & 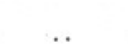 & $\because$ & $\because$. & $\because$ \\
\hline $\begin{array}{l}4 \\
5 \\
6\end{array}$ & $97 \%$ & $\because$ & $\because$. & . & $\because$ & I & $\because$ & $\ddot{x}$ & $\because$. & I small gastropod \\
\hline 6 & $\begin{array}{l}85 \% \\
10 \%\end{array}$ & Few red & $90 \%$ & $\because$ & + & 2 & $\cdots$ & . & $\cdots$ & . \\
\hline 7 & $10 \%$ & fils & green & $\cdots$ & $\cdots$ & $\cdots$ & $\cdots$ & $\cdots$ & $\cdots$ & . \\
\hline $\begin{array}{l}8 \\
9\end{array}$ & $80^{+} \%$ & $\stackrel{+}{+}$ & 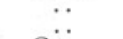 & $\begin{array}{l}\text { tr. } \\
. .\end{array}$ & $\ddot{t}$ & $\because$. & $\because$ & $\because$. & $\because$. & $\cdots$ \\
\hline Io & $90 \%$ &.. & Green & tr. & . & .. & . & .. & . & Many? nematode \\
\hline II & $\cdots$ & $\cdots$ & . & $\cdots$ & $\cdots$ & $\cdots$ & $\cdots$ & . & $\cdots$ & $\begin{array}{l}\text { Manyy? nematode } \\
\text { cuticles }\end{array}$ \\
\hline $\begin{array}{l}12 \\
13\end{array}$ & tr. & $\ddot{\text { tr. }}$ & $\begin{array}{l}90 \% \\
\text { green }\end{array}$ & $\because$ & $\because$ & $\because$ & $\because$ & $\because$ & $\because$ & $\because$ \\
\hline $\begin{array}{l}14 \\
15\end{array}$ & $\because$ & $\begin{array}{c}++ \\
\ldots\end{array}$ & $\begin{array}{c}++ \\
\ldots\end{array}$ & + & $\because$ & $\ddot{\mathrm{I}}$ & Several & $\because$. & $\ddot{I}$ & I chironomid cuticle \\
\hline r6 & ++ & + & . & .. & .. & $\cdots$ & I moult & .. & .. & $\begin{array}{l}\text { I gastropod } \\
\text { I amphipod moult }\end{array}$ \\
\hline \multicolumn{11}{|c|}{ L. serratus } \\
\hline I & tr. & .. & . & . & . & . & 4 moults & I & I & $\begin{array}{l}\text { I chironomid cuticle, } \\
\text { I gastropod }\end{array}$ \\
\hline $\begin{array}{l}2 \\
3\end{array}$ & $\begin{array}{l}75 \% \\
80 \%\end{array}$ & $\begin{array}{l}\text { tr. } \\
\cdots\end{array}$ & $\because$ & $\because$ & $\stackrel{+}{+}$ & 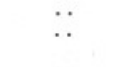 & $\because$ & $\begin{array}{l}\mathrm{I} \\
\mathrm{I}\end{array}$ & $\begin{array}{l}\mathrm{I} \\
\mathrm{I}\end{array}$ & $\begin{array}{l}\text { I chironomid cuticle, } \\
\text { I amphipod head }\end{array}$ \\
\hline $\begin{array}{l}4 \\
5\end{array}$ & $50 \%$ & .. & $\because$. & $\begin{array}{l}+ \\
.\end{array}$ & $\begin{array}{l}30 \% \\
+\end{array}$ & $\because$ & 2 moults & $\ddot{I}$ & $\begin{array}{l}\mathrm{I} \\
. .\end{array}$ & I amphipod moult \\
\hline 6 & tr. & .. & .. & . & $\because$ & .. & I moult & 3 & .. & . \\
\hline 7 & + & .. & . & . & + & .. & $\begin{array}{l}\text { 12 cope- } \\
\text { podites }\end{array}$ & . & .. & . \\
\hline 8 & tr. & $\because$ & $\cdots$ & $\ddot{0}$ & ++ & $\because$ & . & 4 & $\because$ & $\because$ \\
\hline $\begin{array}{r}9 \\
\text { 10 }\end{array}$ & $\begin{array}{l}75 \% \\
85 \%\end{array}$ & $\because$ & 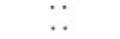 & tr. & $\because$. & $\because$ & 3 moults & $\stackrel{4}{\mathrm{I}}$ & $\because$. & $\because$. \\
\hline II & tr. & .. & . & $\cdots$ & ++ & .. & . & 2 & 2 moults & $\cdots$ \\
\hline $\begin{array}{l}12 \\
13\end{array}$ & $\stackrel{+}{+}$ & $\because$ & . & $\cdots$ & . & .. & moults & 2 & I & I chironomid cuticle \\
\hline 13 & + & $\cdots$ & $\cdots$ & . & .. & $\cdots$ & $\begin{array}{l}3 \text { moults } \\
\text { I cope- } \\
\text { podite }\end{array}$ & $\ddot{I}$ & $\cdots$ & . \\
\hline $\begin{array}{l}14 \\
15\end{array}$ & $8 \ddot{5} \%$ & tr. & $\because$. & $\ddot{t}$ & 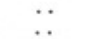 & $\because$ & . & $\begin{array}{l}\mathrm{I} \\
4\end{array}$ & $\because$ & $\because$ \\
\hline 16 & & + & $\therefore$ & .. & $\dddot{+}$ & $\because$ & 4 moults & 9 & $\because$ & $\begin{array}{l}\text { Pt: of } \Psi \text { isopod, } I \\
\text { gastropod, } I \text { chiro- } \\
\text { nomid cuticle }\end{array}$ \\
\hline I7 & $70 \%$ & .. & .. & . & + & . & $\cdots$ & 2 & .. & $\ldots$ \\
\hline
\end{tabular}

The food of the O-group. The food of young prawns less than $30 \mathrm{~mm}$. in length differed rather strikingly from that of larger specimens, notably in the absence of algae and presence of large numbers of ostracods. The exact reverse was found with a sample of Leander squilla taken from the same pool (Table II) which fed chiefly on algae, with some foraminifera but no crustaceans. Both species took a fair amount of debris, of which there was ample. 
Otherwise there was a clear divergence of feeding habits as would be expected from the theory of closely related species occupying the same habitat.

The stomach contents of about I40 L. serratus have been analysed, and show that the food varies from place to place and throughout the year. In general, the species is omnivorous. Algae and small crustaceans appear to form a large proportion of the diet. Much debris was also found in the stomach contents, but there is no reason to consider it of more than slight food value. A great deal more must be known of the digestive powers of prawns and of the composition of the food organisms before definite conclusions can be drawn. It is also impossible to ascertain whether the animals found in the stomach have been captured dead or alive, but since observations have shown that prawns can catch small amphipods and other crustaceans, it may be that their habits are not so much scavenging as is commonly supposed.

\section{Notes ON BEHAVIOUR}

Tidal and diurnal migrations at Rum Bay have been observed. On this shore, which may be taken to represent any fairly sheltered rocky coast, prawns are first seen 2 or $3 \mathrm{hr}$. before low water walking or swimming over the algae moving out with the tide. Where the shore has been eroded into tiny bays and gulleys they often form a steady procession. The larger prawns usually leave first, keeping in 3 or $4 \mathrm{ft}$. of water, and creeping under weed or rocky ledges where possible and thus are less easily observed. Last to leave are the baby Ogroup prawns usually so numerous as to form a steady stream swimming vigorously only a foot or so below the surface. Three-quarters or half an hour before low tide the migration has ceased and most of the prawns are hidden under Laminaria fronds or congregated under ledges or in tunnels, anywhere sheltered from light. Very soon after the tide turns the O-group begin to move in with it, but the larger prawns do not usually return until the water is 4 or $6 \mathrm{ft}$. deep.

During the night there is a migration up the shore, since prawns may be observed with a torch right up in the barnacle zone where they normally never appear by day. The eyes show up very brightly by torchlight, glowing with a fascinating golden iridescence, as was noted almost roo years ago by Warrington (1855). This is well known to many fishermen since they may be caught readily at neap tides in this way.

Prawns in the deeper part of the Laminaria zone can be caught only in hoop-nets or traps after dark, the first being taken usually just after dark. This is a marked difference in behaviour from those on the shore which are definitely attracted to a piece of fish bait in the daytime. It is probable that those in the deeper water remain hidden away during the hours of daylight, which may be related to the presence of predators such as bass, pollack and cuttlefish in this zone. 
In spite of their prominent eyes repeated observations show that prawns appear to make little use of them. The antennal signal reaction to a moving object is occasionally shown, but normally there is only a slight twitch or wave of the antennae without relation to the direction of the object. A sudden movement or change in light intensity will often cause the escape reaction, i.e. a series of vigorous backward flaps of the abdomen.

Food seems to be located first by scent and then by the antennae, since a prawn may even walk right over a piece of food if the antennae have failed to touch it.

Mating also appears to be a response to chemical stimuli, associated with the soft cuticle of a recently moulted female with a ripe ovary, since the males are only attracted to females in this state (Höglund, I943; Burkenroad, I947). If an 'attractive' female is placed in a tank with males nothing happens until the antenna of a male touches some part of the female. At once the male's behaviour alters, he swims very rapidly in no particular direction, often making small circles, until he again makes contact even though the female had been only a few centimetres away. As this was frequently observed, it seems that the male can have no visual perception of the female.

\section{SUMMARY}

An attempt has been made to follow the post-larval life history of Leander serratus through I year.

Growth has been followed from length measurements of numerous samples of populations obtained by several different methods. Owing to the length of the breeding season and especially to the differing habitat preferences of the various size groups in the littoral and sublittoral zones, estimates of their rate of growth are necessarily approximate.

After metamorphosing, apparently in very shallow water, during July the O-group grew rapidly, their average length by October being in the region of $5 \mathrm{~cm}$. There was a marked difference in length between the October catches of I949 and I950, and reasons have been given for correlating this with the differing temperatures of these 2 years. Growth almost ceased during the winter, and not until June was there a marked change in the size frequencies. In their second summer's growth females outstripped the males, the mean lengths in October being approximately 9 and $7.5 \mathrm{~cm}$. respectively. There appeared to be a very high mortality in the third summer, with scarcely any surviving to the autumn. However, occasional extra large prawns were trawled during the winter so that a definite conclusion on the limit of age is impossible.

The breeding season, judged by the presence of berried females, lasted from November until June (1949-50). Maturity in the smallest males of the O-group was reached at least in December and with the smallest females in March. 
With increase in size spawning took place earlier and the numbers which spawned twice increased. Some of the largest prawns may have produced a third brood. The period of egg-carriage was about 4 months at roughly 9-II ${ }^{\circ} \mathrm{C}$.

The distribution in winter varied according to the habitat. There was a tendency to leave the estuaries. In the Sound the male prawns were widely distributed in depths of 4-5 fathoms on a muddy bottom, while the females, judging from their scarcity in the trawl catches, were more restricted to the rocky parts. The spring inshore movement took place during April and May, with some variation between different years, apparently unrelated to temperature. During early summer, trap catches showed a marked discontinuity in the distribution of the size groups, the larger prawns being taken only in the sublittoral zone. On exposed rocky coasts prawns overwintering the second time moved into deeper water, from Io to 15 fathoms, and have sometimes been of value to lobster fishermen.

Examination of the stomach contents, though often difficult, showed that the species was in general omnivorous. Algae and small Crustacea appeared to be the chief sources of food. Much debris was also taken; this is tentatively considered of lesser importance.

Small-scale tidal and nocturnal migrations have been observed. The results of catches with baited traps show that prawns in the sublittoral zone tend to be markedly nocturnal in their habits, compared to those observed on the shore.

From laboratory and field observations the eyes are thought to be of much less use than their size would suggest. Prawns may perceive sudden movements visually, but they cannot apparently avoid obstacles, locate pieces of food, or in case of the males find a mate, without the use of their antennae.

\section{REFERENCES}

Burkenroad, M. D., I947. Reproduction activities of decapod Crustacea. Amer. Nat., Vol. I3I, pp. 392-8.

Fretter, V. \& Graham, A., I949. Structure and mode of life of the Pyramidellidae, parasitic opisthobranchs. Fourn. Mar. Biol. Assoc., Vol. 28, pp. 493-533.

GuRNEy, R., I923. Some notes on Leander longirostris M. Edwards, and other British prawns. Proc. Zool. Soc. Lond., Vol. I, pp. 97-I23.

- I924. The larval development of some British prawns. II. Leander longirostris and L. squilla. Proc. Zool. Soc. Lond., Vol. 2, pp. 961-82.

HögLund, H., 1943. On the biology and larval development of Leander squilla (L.) forma typica de Man. Svenska Hydrograph. Biol. Komm. Skr. Ny serie: Biol. Bd. 2, pp. I-43.

Hunt, O. D., I925. The food of the bottom fauna of the Plymouth fishing grounds. Fourn. Mar. Biol. Assoc., Vol. 13, pp. 560-98.

Kemp, S., I9Io. The Decapoda Natantia of the coasts of Ireland. Dept. of Agriculture and Technical Instruction of Ireland. Fisheries Branch. Sci. Inv. I908, pp. I-I90.

Lebour, M. V., I947. Notes on the inshore plankton of Plymouth. Fourn. Mar. Biol. Assoc., Vol. 26, pp. 527-47. 
Lloyd, A. J. \& Yonge, C. M., I947. The biology of Crangon vulgaris in the Bristol Channel and Severn Estuary. Fourn. Mar. Biol. Assoc., Vol. 26, pp. 626-6r.

Lumby, J. R., I935. Salinities and temperatures of the English Channel. Fish. Invest., Series II, Vol. I4, No. 3.

Marine Biological Association, 193i. Plymouth Marine Fauna. 2nd ed.

Needham, J., I931. Chemical Embryology, Vol. I. Cambridge University Press.

Nouvel, H. \& van Rysselberge, L., I937. Contribution à l'étude de la mue, de la croissance, et de la régéneration chez les crustacés natantia. Rec. Inst. Zool, Torley-Rousseau, T. 6, pp. 9-I6r.

PanNikar, N. K., I94I. Osmoregulation in some palaemonid prawns. Fourn. Mar. Biol. Assoc., Vol. 25, pp. 317-55.

Percival, E., 1929. A report on the fauna of the River Tamar and the River Lynher estuaries. Fourn. Mar. Biol. Assoc., Vol. 16, pp. 8I-108.

Poulsen, E. M., I946. Investigations on the Danish fishery for, and the biology of, the Norway lobster and the deep-sea prawn. Rep. Danish Biol. Stat., Vol. 48, pp. 29-47.

RusSELL, F. S., I927. The vertical distribution of marine macroplankton. V. The distribution of animals caught in the ring-trawl in daytime in the Plymouth area. Fourn. Mar. Biol. Assoc., Vol. 14, pp. 557-608.

Sollaud, E., I9I6. Recherches sur la bionomie des 'Palémonides' des côtes de France. Rec. Fonds. Bonaparte, T. I, pp. 69-7I.

— 1923. Le développement larvaire des 'Palaemoninae'. Bull. Biol. France et Belg., T. 57, pp. 510-602.

WARRINGTON, R., I855. Observations on the natural history and habits of the common prawn. Ann. Mag. Nat. Hist. Ser. 2, Vol. 15, pp. 247-52. 